Sunarningsih ${ }^{1}$
Cahyaningtyas $^{2}$ dan Yuka Nurtanti

${ }^{1}$ Balai Arkeologi Kalimantan Selatan, Jalan Gotong Royong II Rt.03/06, Banjarbaru Kalimantan Selatan, Indonesia; posel: asihwasita@gmail.com

${ }^{2}$ Pusat Penelitian Arkeologi Nasional, Jalan Raya Condet Pejaten No. 4, Pasar Minggu, Jakarta Selatan, Indonesia; posel: yuka.nurtanti@kemdikbud.go.id

Diterima: 2 September 2021

Direvisi: 5 November 2021

Disetujui: 10 November 2021

\section{PUSAT KERAJAAN TAYAN DI BUKIT RAYANG, SANGGAU, KALIMANTAN BARAT}

\author{
THE CENTER OF TAYAN KINGDOM IN BUKIT \\ RAYANG, SANGGAU, WEST KALIMANTAN
}

\begin{abstract}
Abstrak. Salah satu kerajaan Islam yang berada di aliran Sungai Kapuas, Kalimantan Barat adalah Kerajaan Tayan. Pusat kekuasaan awal berdirinya kerajaan ini berada di aliran Sungai Tayan yang merupakan anak Sungai Kapuas, tepatnya di Bukit Rayang sebelum akhirnya pusat pemerintahannya berada di Teluk Kemilun yang bangunan Keraton dan masjidnya masih berdiri kokoh hingga sekarang. Keberadaan Bukit Rayang menarik untuk diteliti karena masih minimnya data awal pusat kekuasaan Tayan tersebut. Tujuan penelitian ini untuk mengetahui ragam data arkeologi dan lanskap hunian di Bukit Rayang. Metode pengumpulan data menggunakan survei dan ekskavasi. Data selanjutnya dianalisis, baik lingkungan maupun artefaktualnya. Hasil penelitian mendapatkan beragam data arkeologi, yaitu benteng tanah, bekas pemandian putri, tonggak bekas jembatan, makam kerabat istana, tonggak bekas masjid, bekas pendapa, meriam, dan artefak berupa fragmen dari bahan yang beragam (tanah liat, Stoneware, porselen, kaca, logam, dan batu). Berdasarkan hasil analisis artefaktual, temuan fragmen berasal dari berbagai bentuk wadah dan nonwadah yang digunakan oleh masyarakat pendukung Kerajaan Tayan, dan analisis lingkungan memberi gambaran lanskap hunian di lokasi Bukit Rayang sangat strategis karena berada di kelokan sungai, pengawasan ke arah hulu dan hilir mudah dilakukan, juga keberadaan benteng di bagian tertinggi dari bukit memiliki tujuan untuk mengamankan pengiriman upeti dari wilayah hulu.
\end{abstract}

Kata kunci: lanskap, porselen, benteng tanah, Bukit Rayang, Tayan

\begin{abstract}
The first center of Tayan kingdom was established in Tayan River, precisely in Bukit Rayang. Eventually, the palace has been moved to Teluk Kemilun. Data from Bukit Rayang are still limited so the study purpose is to determine the variety of archaeological data and residential landscapes. The methods were using survey and excavation. The data were analyzed both by environment and artifactual. The results obtained various archaeological data, namely earth fort, princess bath, bridge pillars, tombs, mosque pillar, pendapa, cannon, and fragments of various artifact materials (ceramic, glass, metal, and stone). The findings of fragments came from various forms of containers and noncontainers used by people who supported the Kingdom. The residential landscape was strategic on a river bend so that monitoring activity toward upstream and downstream were easier, and the fort location was suitable with the aim of securing tribute delivery from upstream.
\end{abstract}

Keywords: landscape, ceramic, earth fort, Bukit Rayang, Tayan

\section{PENDAHULUAN}

Kalimantan Barat memiliki beberapa kerajaan yang tumbuh dan berkembang pesat pada masa Islam, yaitu Matan, Mempawah, Sambas, Landak, Tayan, Sanggau, Sekadau, Sintang, dan Pontianak (Kusnoto dan Firmansyah 2016). Kerajaan Matan di Ketapang menjadi kerajaan Islam tertua, dan sebelumnya sudah ada penguasa di tempat tersebut yang berlatar belakang agama Hindu, yaitu Tanjungpura (Smith dan Smith 2011). Beberapa peninggalan Kerajaan Tanjungpura yang bercorak Hindu di Ketapang adalah kompleks makam keramat tujuh dan keramat sembilan yang nisannya mirip nisan Troloyo (Sarjiyanto dan Inagurasi 2018) serta temuan bagian kaki candi dari bata (Cahyaningtyas 2013; Atmojo 2014).

Salah satu kekuasaan di bawah Kerajaan Matan adalah kerajaan Tayan yang berada di aliran Sungai Tayan. Gusti Lekar diperintahkan oleh kakaknya, yaitu Raja Matan untuk mengamankan upeti yang berasal dari wilayahnya yang sering tidak sampai karena dibajak di tengah perjalanan. Selanjutnya, Gusti Lekar dibantu oleh Kai Jaga, seorang Dayak berhasil mengalahkan perompak dan mengamankan upeti, hingga akhirnya berkuasa di wilayah Tayan. Kerajaan 
Tayan mulai berkuasa dari tahun 1687 hingga 1965 (Sitio 2018).

Bukit Rayang yang terletak di hulu Sungai Tayan, dikenal masyarakat sebagai tempat berdirinya keraton pertama Kerajaan Tayan yang didirikan oleh Gusti Lekar. Bangunan keraton sebagai pusat kekuasaan masih berdiri dengan kokoh di Teluk Kemilun.

Bukit Rayang yang pernah digunakan sebagai pusat kerajaan tersebut sekarang sudah tidak dimanfaatkan lagi oleh masyarakat sebagai tempat tinggal. Untuk mencapai lokasi situs, lebih mudah melalui jalur sungai, dari Kota Tayan, menyusuri Sungai Tayan ke arah hulu. Terdapat satu desa terdekat dengan situs, yaitu Desa Melugai yang berada di arah hilir Bukit Rayang.

Sebagai bekas pusat kerajaan tentunya meninggalkan bekas yang dapat ditemukan kembali. Pemilihan lokasi sebagai pusat kekuasaan sangat penting, banyak pertimbangan dilakukan berkaitan dengan daya dukung lingkungannya. Permasalahan dalam penelitian ini adalah

1. Apa sajakah ragam data arkeologi yang ditemukan di Bukit Rayang?

2. Bagaimanakah lanskap hunian di Bukit Rayang?

Jadi, tujuan penelitian adalah untuk mengetahui ragam data arkeologi dan lanskap hunian di Bukit Rayang.

\section{METODE}

Penelitian arkeologi ini bersifat deskriptif dengan penalaran induktif. Data dikumpulkan menggunakan metode survei dan ekskavasi, sedangkan analisis artefak dilakukan secara morfologi untuk mengetahui bentuk, fungsi, dan kronologinya (Renfrew dan Bahn 2012). Untuk mendukung sintesis dan interpretasi data digunakan studi pustaka. Hasil analisis artefak disajikan dalam tabel dan juga dibuat peta lokasi dan situasi situs berdasarkan data GPS yang diambil pada saat penelitian berlangsung.

\section{HASIL DAN PEMBAHASAN}

Permukiman awal di Kalimantan Barat berada di sepanjang tepian sungai, termasuk di aliran Sungai Kapuas (Purmintasari dan Kusnoto
2018), demikian juga dengan keberadaan kerajaan bercorak Islam tersebut berada di tepi sungai (Andi 2017). Pada masa Pra-kolonial dan Kolonial, daerah aliran sungai Kalimantan dikendalikan oleh pemerintahan perdagangan, baik kesultanan yang kuat maupun pemerintahan kecil, yang kedudukannya terletak di muara sungai dan pertemuan anak-anak sungai utama (Sellato 2015).

Hal yang sama juga tampak di Bukit Rayang, tidak berada di tepi sungai besar, tetapi anak Sungai Kapuas, yaitu Sungai Tayan. Selanjutnya, kajian lanskap dalam arkeologi antara lain ditujukan untuk mengetahui konsep, bagaimana masyarakat pendukung menata dan mengubah lingkungannya sesuai kebutuhan mereka. Dari lanskap tersebut dapat diketahui bagaimana tempat tersebut membentuk tingkah laku dan identitas masyarakat pendukungnya (Branton 2009; Gojda 2004). Oleh karena itu, proses pengumpulan data penelitian dengan cara survei permukaan dan juga ekskavasi yang hasilnya akan diuraikan berikut ini.

\section{Hasil Survei}

Bukit Rayang dipercaya oleh masyarakat merupakan tempat kedudukan awal dari Kerajaan Tayan. Bukit ini berada tidak jauh dari Keraton Tayan terakhir yang berkedudukan di Teluk Kemilun. Berbeda dengan bangunan keraton di Teluk Kemilun yang masih berdiri megah hingga saat ini, bangunan keraton di Bukit Rayang saat ini sudah tidak ada lagi.

Letak bukit ini berada di belokan sungai dan pertemuan beberapa sungai, antara lain menuju Batang Taran, Sosok, Landak, dan sungai kecil ke arah belakang bukit. Untuk menuju Bukit Rayang lebih mudah dilakukan melalui jalur air. Desa yang paling dekat dengan situs adalah Desa Melugai, yang juga dijadikan basecamp pada saat tim penelitian melakukan pengumpulan data (Gambar 1).

Secara umum stratigrafi lokal Bukit Rayang termasuk dalam Formasi Pedawan (Supriatna dkk. 1993). Formasi ini meliputi antara lain lapisan batuan serpih, serpih batu sabak, batu lumpur karbonan, batu lanau dan batu pasir, setempat gampingan, terdapat sedikit batu gamping dan tufa, serta mengandung fosil. Endapan tepi Sungai 
Tayan merupakan Endapan aluvial yang terdiri atas lumpur, pasir, kerikil serta bahan tumbuhan. Di bagian selatan Sungai Tayan terdapat batuan malihan pinoh yang tersusun antara lain oleh batu sabak, filit, kuarsit, sekis, amfibolit, genes, dan migmatit.

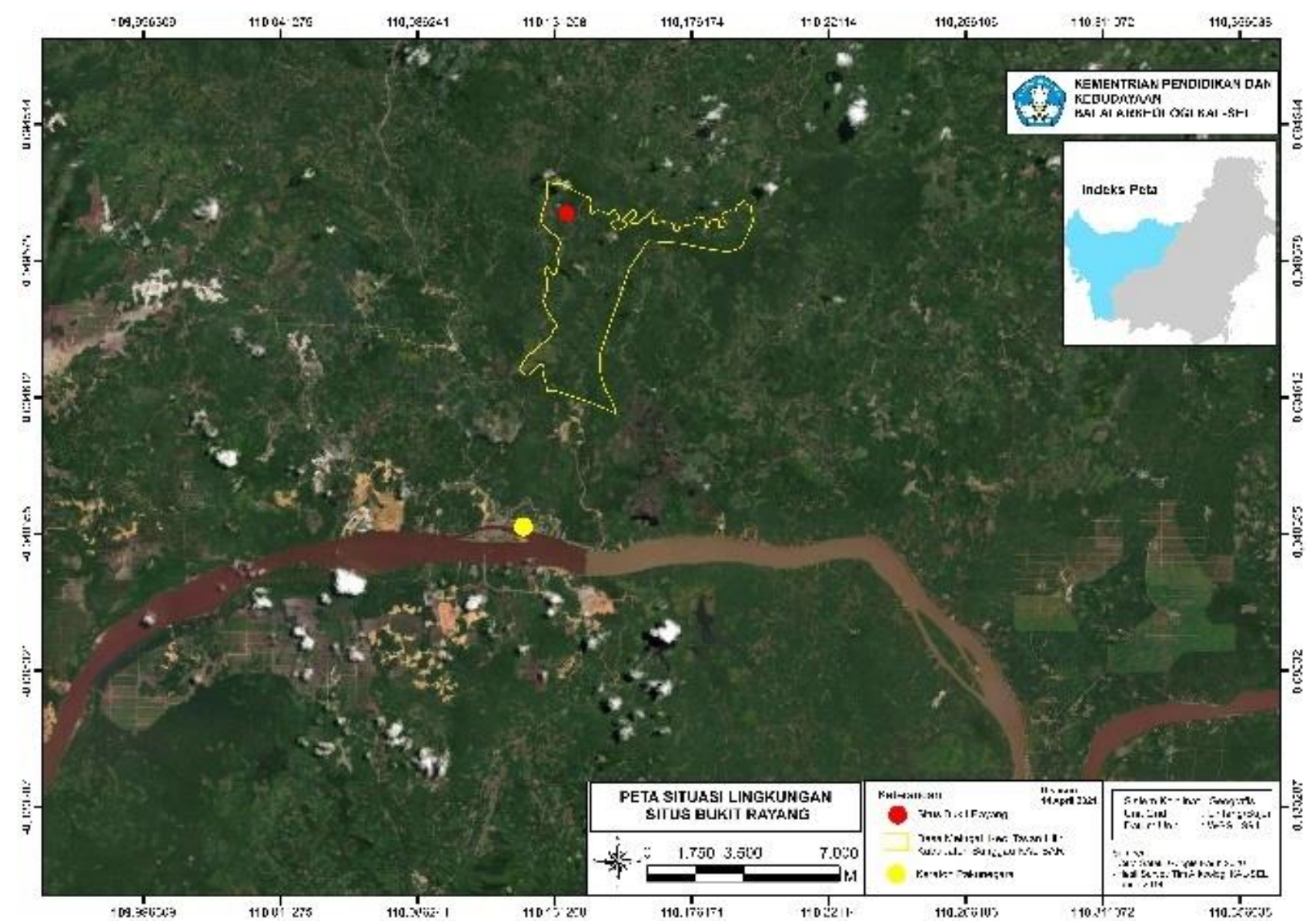

Sumber: Dok. Balar Kalsel 2021

Gambar 1 Lokasi situs Bukit Rayang

Hasil survei di Bukit Rayang dan sekitarnya menjumpai beberapa peninggalan yang berhubungan dengan pusat kerajaan. Temuan tersebut dapat dilihat pada Gambar 2.

Benteng berbentuk persegi, dua sudutnya dilengkapi bastion berbentuk segi empat, tingginya sekitar 3 meter, dan terbuat dari tanah (Gambar 3). Benteng berada di bagian tertinggi, dan ditumbuhi oleh pohon karet, halaman tengah benteng berjarak 6 meter dari bagian dinding teratas. Sebagian benteng sudah runtuh, tetapi $70 \%$ nya masih utuh. Sebelah barat daya benteng dan menjauhi arah sungai terdapat bekas pemandian putri dengan tanda batu, tampak seperti aliran sungai mati (guntung) di punggung bukit.

Temuan meriam di lereng bukit dengan orientasi timur barat berada sekitar 200 meter dari tepi sungai. Meriam sudah dipindahkan dari tempatnya semula karena posisi moncongnya mengarah ke bukit yang lebih tinggi. Ukuran meriam yaitu panjang 195 meter, diameter ujung bagian bawah $31 \mathrm{~cm}$, diameter moncongnya 18 $\mathrm{cm}$, Bekas pendapa berfungsi sebagai tempat penjaga keraton berada di tepi sungai. Tidak ada lagi sisa bangunannya, dan titik lokasi pendapa diketahui berdasarkan informasi dari masyarakat.

Kuburan berada di dekat meriam, ke arah yang lebih tinggi. Berisi kuburan keluarga raja, nisan orientasi utara selatan. Bahan nisan terdiri atas kayu belian (besi), batu granit, dan beton. Hampir semua nisan tidak memiliki jirat, kecuali satu nisan yang berada di sisi barat. Hanya ada tiga yang memiliki inskripsi Arab berbahasa Melayu. Nisan yang bertulisan tersebut terbuat dari beton, dibuat dengan sistem cetakan, yaitu Baharudin 18 Maret 1923, Gusti Hasan Basri 1962, dan Hamdan bin Jalal 2001. Bentuk nisannya beragam, nisan gada dari kayu belian, nisan 
bentuk pipih dan bulat dengan ujung runcing dari batu granit, nisan ujung runcing bertingkat (ujung), membulat (tengah), dan persegi berundak (bawah) dari beton.

Sisa satu tonggak masjid ada di ujung belokan sungai, terbuat dari kayu ulin dengan diameter $\pm 40 \mathrm{~cm}$. Pada saat survei posisinya jatuh di bibir sungai oleh gerusan aliran sungai.
Seberang tiang masjid (seberang sungai) terdapat sisa tonggak jembatan, yang berada di daratan yang sama dengan Bukit Rayang. Tiga tiang yang sudah keropos, sebagian tiang menancap di dalam tanah. Dahulu, jembatan digunakan untuk menghubungkan bukit dengan hunian di seberang sungai.

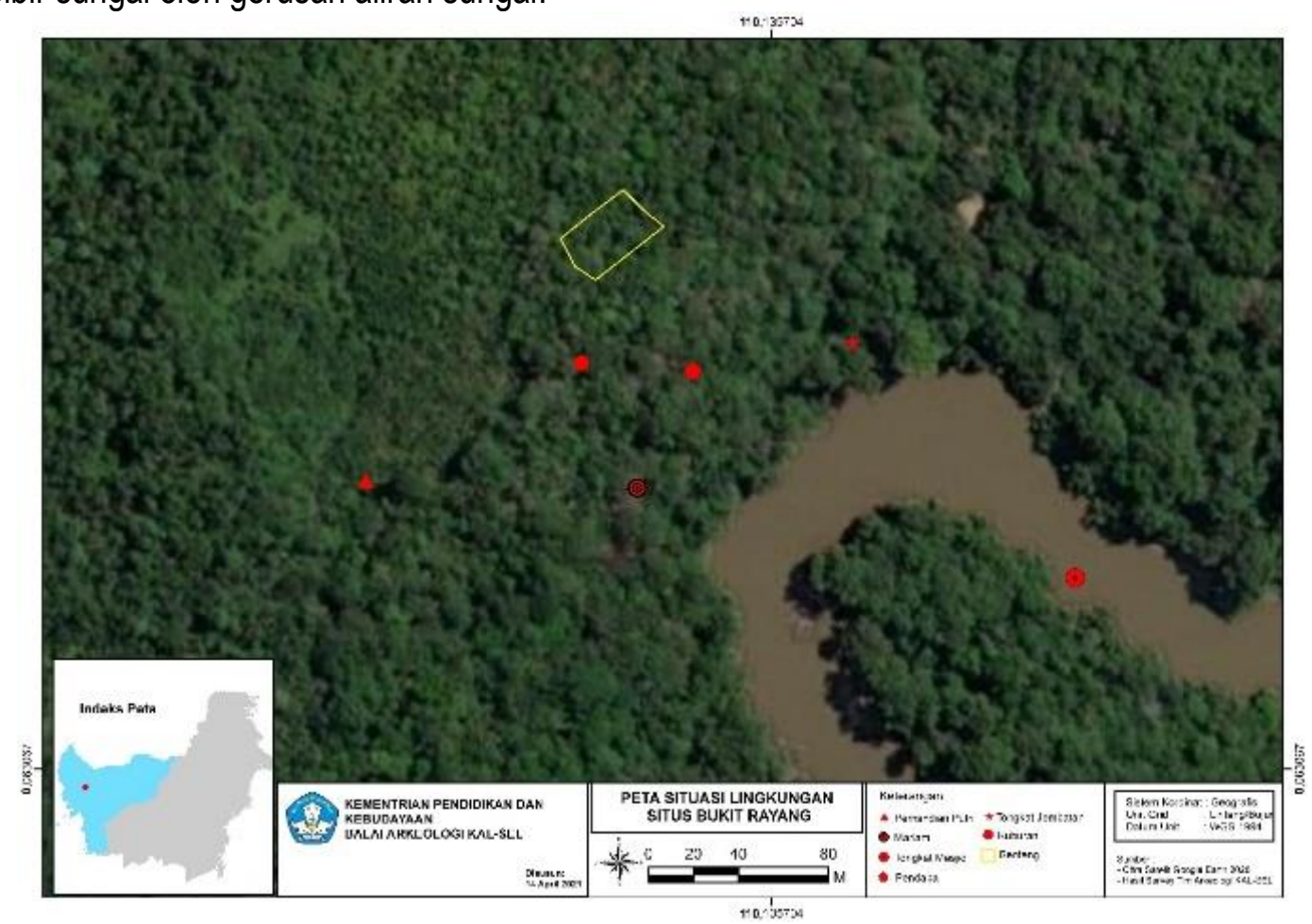

Sumber: Dok. Balar Kalsel 2021

Gambar 2 Sebaran Temuan di Bukit Rayang

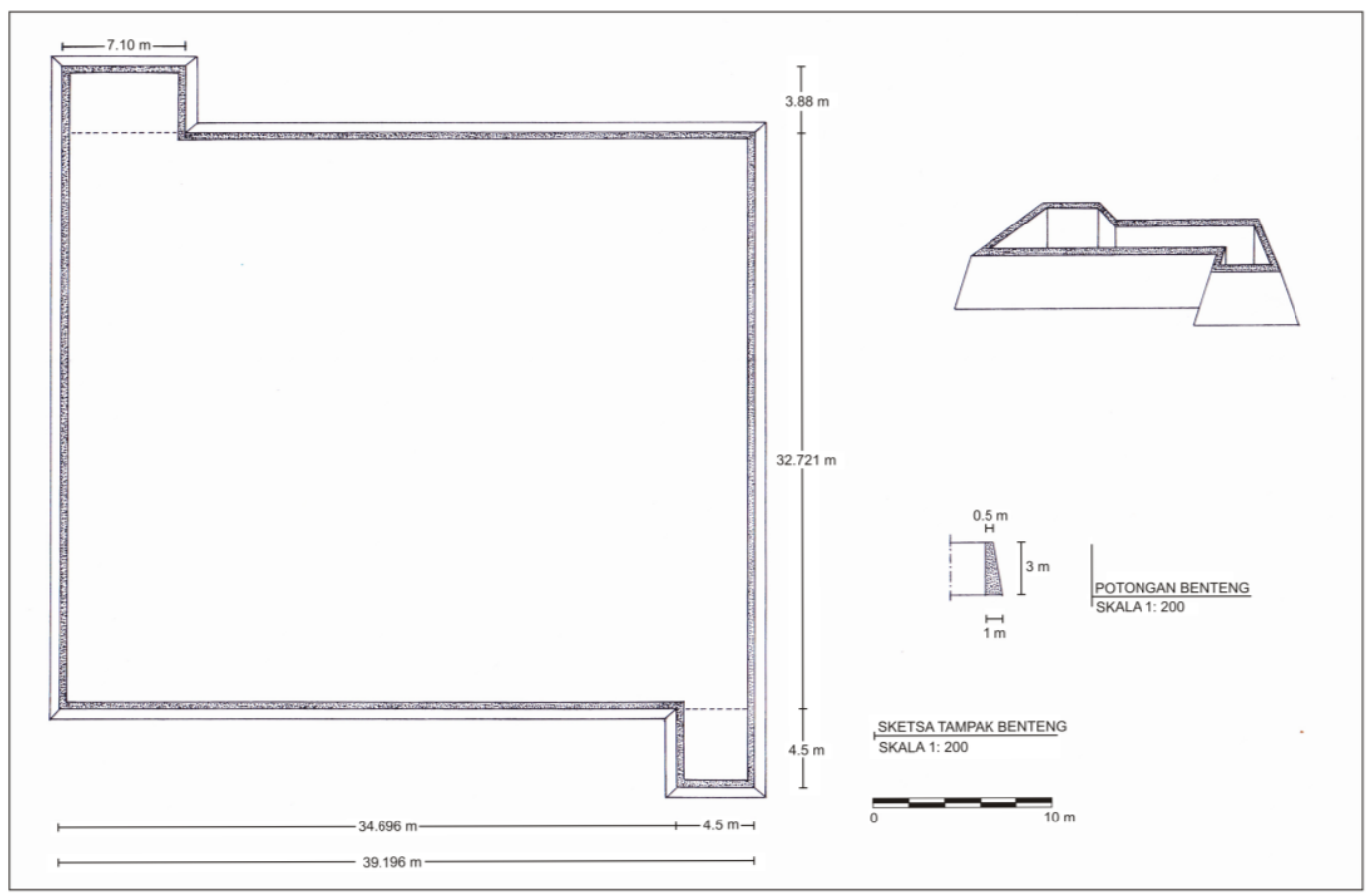

Sumber: Dok. Balar Kalsel 2014

Gambar 3 Denah Benteng Tanah Bukit Rayang 
Selain lokasi sisa pusat pemerintahan tersebut, di beberapa titik permukaan tanah juga ditemukan fragmen porselen berbahan earthenware, Stoneware, dan porselen. Fragmen porselen tersebut dikumpulkan dan dianalisis morfologinya.

\section{Hasil Ekskavasi}

\section{TP 1}

Kotak TP 1 dibuka dengan tujuan untuk mencari sisa hunian di tepi sungai, dataran yang lebih rendah dari benteng. Jadi, letak kotak ini berada di antara sungai dan benteng tanah yang berdasarkan informasi anggota keluarga kerajaan lokasi di antara tepi sungai dan benteng tanah tersebut dulunya merupakan tempat berdirinya istana Kerajaan Tayan yang pertama, yang dibangun oleh Gusti Lekar. Kotak ini berada di depan sisi benteng, dengan jarak ke benteng sekitar 100 meter.

Kotak TP 1 berukuran $2 \times 2$ meter, dan digali separuhnya dengan ukuran $1 \times 2$ meter di sisi sebelah timur. Untuk mendalami kotak ini digunakan sistem spit dengan interval antarspit 20 $\mathrm{cm}$. Oleh karena kondisi permukaan tanah di sebelah utara lebih tinggi daripada sisi selatan, maka spit (1) mempunyai kedalaman $30 \mathrm{~cm}$, dan spit selanjutnya $20 \mathrm{~cm}$. Konsentrasi temuan kebanyakan berada di spit (1), dan sedikit di spit (2) (di sisi selatan; Tabel 1). Meskipun berada di dua spit, tetapi temuan hanya berada di lapisan tanah pertama yang berupa tanah humus warna hitam dengan tekstur lepas (pasir lempungan; Gambar 4). Perubahan lapisan tanah mulai terlihat di spit (2), tanah humus berwana hitam berganti dengan tanah yang liat dan lebih kompak berwarna merah terang. Penggalian di spit (3) hanya dilakukan di sisi selatan, dengan ukuran $1 \times 1$ meter, tanpa adanya temuan artefaktual. Sampai dengan akhir penggalian, yaitu spit (5), warna tanah tidak berubah dan tanpa temuan.

Tabel 1 Temuan di TP 1

\begin{tabular}{|l|l|l|l|}
\hline No. & Spit & \multicolumn{1}{|c|}{ Jenis Temuan } & Jumlah \\
\hline 1 & $(\mathrm{P})$ & Fragmen Stoneware & 7 \\
\hline & & Fragmen besi & 1 \\
\hline & & Koin & 1 \\
\hline & & Fragmen porselen Eropa & 19 \\
& & & 1 \\
\hline & & Kaca tutup & 1 \\
\hline
\end{tabular}

\begin{tabular}{|c|c|c|c|}
\hline No. & Spit & Jenis Temuan & Jumlah \\
\hline & & Fragmen kaca badan & 1 \\
\hline & (1) & Serpih batu & 1 \\
\hline & & Batu asah & 1 \\
\hline & & Fagmen batuan & 21 \\
\hline & & Batu kuarsa & 5 \\
\hline & & Fragmen porselen Cina & 55 \\
\hline & & Fragmen porselen modern & 5 \\
\hline & & Fragmen Stoneware & 38 \\
\hline & & Fragmen besi & 6 \\
\hline & & $\begin{array}{l}\text { Fragmen } \\
\text { gerabah/earthenware }\end{array}$ & 36 \\
\hline & & $\begin{array}{l}\text { Fragmen topeng } \\
\text { Stoneware }\end{array}$ & 1 \\
\hline & & Damar & 1 \\
\hline & & $\begin{array}{l}\text { Fragmen Stoneware tanpa } \\
\text { glasir }\end{array}$ & 4 \\
\hline & & Fragmen kaca & 17 \\
\hline & & Fragmen porselen Eropa & 35 \\
\hline & & Mata uang kepeng & 1 \\
\hline & (2) & Batu merah (hematit) & 5 \\
\hline & & Fragmen porselen Cina & 4 \\
\hline & & Fragmen earthenware & 1 \\
\hline & & Fragmen porselen Eropa & 1 \\
\hline & & Fragmen Stoneware & 4 \\
\hline
\end{tabular}

Sumber : Hasil Penelitian 2014

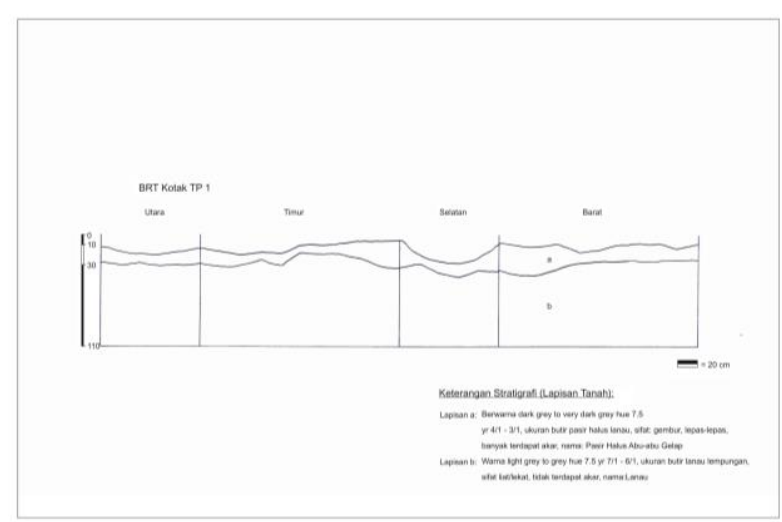

Sumber: Dok. Balar Kalsel 2014

Gambar 4 Stratigrafi TP1

\section{TP 2}

Kotak TP 2 berada di sebelah selatan lokasi bangunan yang diperkirakan sebagai keraton. Salah satu pertimbangan dalam pembukaan kotak TP 2 ini adalah untuk mengetahui persebaran temuan permukaan di sekitar lokasi Keraton berada. Kondisi permukaan kotak sebelum dibersihkan sedikit ditumbuhi dengan rumputrumputan dan beberapa tumpukan daun yang lembab. Di sekitar kotak TP 2 terlihat tanaman karet dan beberapa tanaman semak lainnya. Kotak ekskavasi TP 2 ini dibuat dengan ukuran $2 \times 2$ m, 
namun penggalian hanya dilakukan pada separuh kotak, yaitu berukuran $2 \times 1 \mathrm{~m}$ yang merupakan sisi bagian timur. Penggalian pada kotak TP 2 ini dilakukan sampai dengan spit (4). Temuan pada kotak TP 2 dapat dilihat pada Tabel 2.

Tabel 2 Temuan di TP 2

\begin{tabular}{|c|c|l|c|}
\hline No. & Spit & \multicolumn{1}{|c|}{ Jenis Temuan } & Jumlah \\
\hline 1 & $(\mathrm{p})$ & Fragmen porselen & 18 \\
\hline & & Fragmen Stoneware & 1 \\
\hline & $(1)$ & Fragmen porselen & 39 \\
\hline & & Fragmen Stoneware & 6 \\
\hline & & Fragmen tulang terbakar & 1 \\
\hline & & Kancing plastik & 1 \\
\hline
\end{tabular}

\begin{tabular}{|c|c|l|c|}
\hline No. & Spit & \multicolumn{1}{|c|}{ Jenis Temuan } & Jumlah \\
\hline & & Batu warna merah & 1 \\
\hline & & Batu kuarsa & 5 \\
\hline & & Fragmen logam & 9 \\
\hline & $(2)$ & Fragmen kaca & 1 \\
\hline & $(3)$ & Arang & 1 \\
\hline & $(4)$ & - & kosong \\
\hline
\end{tabular}

Sumber : Hasil Penelitian 2014

Stratigrafi di TP 2 (Gambar 5) terdiri atas dua lapisan tanah, dan temuan artefak juga ditemukan di lapisan pertama yang berwarna gelap dengan kandungan pasir dan teksturnya gembur, bercampur dengan humus dan akar tumbuhan.

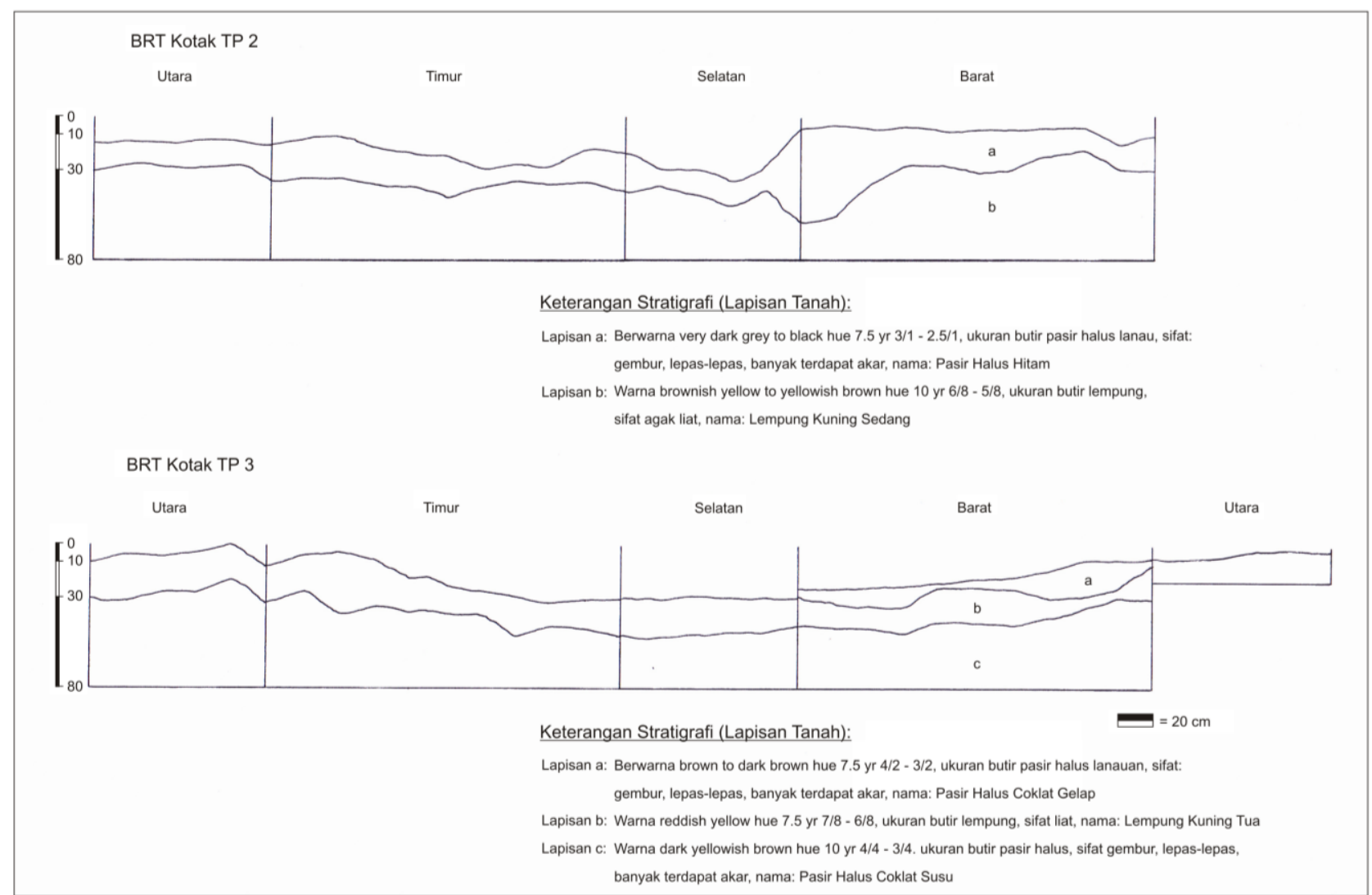

Sumber: Dok. Balar Kalsel 2014

Gambar 5 Stratigrafi TP 2 dan TP 3

TP 3

Kotak TP 3 berada tepat di atas lokasi meriam. Kotak gali TP 3 ini dibuka dengan mempertimbangkan sebaran temuan permukaan yang terletak di dekat meriam. Kondisi permukaan TP 3 ini sebelum dibersihkan ditumbuhi rerumputan dan terdapat tumpukan daun lembap di beberapa tempat. Daerah di sekitar TP 3 belum seluruhnya dimanfaatkan untuk menanam tanaman produktif, hanya ada pohon karet dan kopi, sedangkan lainnya masih berupa semaksemak. Kotak ekskavasi dibuat dengan ukuran $2 \mathrm{x}$ 2, digali 1 spit pada sisi barat, dan 4 spit pada sisi timur. Temuan pada kotak TP 3 dapat dilihat pada Tabel 3. 
Tabel 3 Temuan di TP 3

\begin{tabular}{|c|c|l|c|}
\hline No. & Spit & \multicolumn{1}{|c|}{ Jenis Temuan } & Jumlah \\
\hline 1 & $(\mathrm{P})$ & Fragmen porselen & 44 \\
\hline & & Bauksit & 5 \\
\hline & $(1)$ & Fragmen porselen & 56 \\
\hline & & $\begin{array}{l}\text { Pecahan batusabak } \\
\text { (slate) }\end{array}$ & 18 \\
\hline & $(2)$ & Fecahan granit & 1 \\
\hline & & Fragmen porselen & 17 \\
\hline & & Pecahan kuarsit & 7 \\
\hline & & Pecahan granit & 1 \\
\hline & $(3)$ & Fragmen porselen & 4 \\
\hline & & Fragmen Stoneware & 5 \\
\hline & & Pecahan kuarsit & 1 \\
\hline & & Pecahan granit & 1 \\
\hline & Bauksit & 1 \\
\hline
\end{tabular}

Sumber : Hasil Penelitian 2014

Stratigrafi di TP 3 (Gambar 5) terdiri atas 3 lapisan, tampaknya sudah terjadi pengolahan tanah di tempat ini (sudah teraduk). Lapisan pertama berwarna gelap dengan kandungan pasir, tekstur gembur dan bercampur dengan humus dan akar. Lapisan kedua lebih liat berwarna kuning kemerahan, sedangkan lapisan ketiga warna kuning cokelat bercampur pasir, gembur, dan bercampur dengan akar. Artefak ditemukan pada lapisan pertama dan kedua.

\section{TP 4}

Kotak TP 4 berada tepat di depan sudut benteng sebelah selatan dengan ukuran $2 \times 2$ meter, bertujuan untuk mengetahui sebaran temuan artefaktual di halaman benteng, yang berdasarkan informasi penduduk dulu digunakan sebagai tempat latihan prajurit. Tidak seluruh kotak TP 4 ini digali, hanya dibuka di sisi barat dengan ukuran $1 \times 1$ meter.

Sebelum dibersihkan, permukaan kotak ini dipenuhi oleh semak, akar pohon dan pohon karet dengan ukuran kecil, sedang, dan besar. Setelah permukaan kotak dibersihkan tidak ditemukan artefak. Spit (1) digali pada kedalaman $30 \mathrm{~cm}$ dari titik SDP, spit selanjutnya digali dengan interval 20 cm (Gambar 6). Pada spit (1) ditemukan beberapa fragmen porselen. Jenis tanah pada spit ini relatif gembur bercampur dengan humus pada permukaan tanah, dengan komposisi pasir dominan (pasir lempungan) warna abu-abu kehitaman yang sangat tipis dan mulai bercampur dengan warna cokelat terang sampai dengan spit (2). Selanjutnya, mulai spit (3) sampai dengan spit (4), warna tanah berubah menjadi kuning kemerahan. Tanah ini lebih liat dan sedikit kompak. Tidak ada temuan artefak di spit (2) sampai spit (4). Temuan pada kotak TP 4 dapat dilihat pada Tabel 4.

Tabel 4 Temuan di TP 4

\begin{tabular}{|l|l|l|l|}
\hline No. & Spit & Jenis Temuan & Jumlah \\
\hline 1 & $(1)$ & Fragmen porselen asing & 7 \\
\hline & & Fragmen Stoneware & 1 \\
\hline
\end{tabular}

Sumber : Hasil Penelitian 2014

\section{TP 5}

Kotak TP 5 berjarak sekitar 100 meter dari TP 4 di arah tenggara, dengan perbedaan ketinggian sekitar 5 meter (TP 5 lebih rendah daripada TP 4). Kotak TP 5 berukuran $2 \times 2$ meter, tetapi yang digali hanya $1 \times 1$ meter di sisi sebelah barat laut. Kotak TP 5 dibuka dengan tujuan untuk mengetahui sebaran artefak di area antara TP 2 dan TP 3. Permukaan kotak sebelum dibersihkan ditumbuhi semak belukar dan akar pohon, vegetasi di sekelilingnya ditumbuhi oleh pohon karet dari berbagai ukuran dan pohon berbatang keras lainnya. Tidak ada temuan artefak di permukaan kotak.

Spit (1) memiliki kedalaman $20 \mathrm{~cm}$, dan jarak interval antarspit adalah $20 \mathrm{~cm}$ (Gambar 6). Pada spit (1) ditemukan beberapa artefak, yang terdiri atas fragmen gerabah dan porselen dan Stoneware dengan jumlah yang tidak terlalu banyak. Warna tanah di spit ini abu-abu kehitaman dengan kandungan pasir yang lebih banyak dan gembur. Spit (2) masih memiliki jenis dan warna tanah yang sama. Menginjak spit yang ke-3, tanah berubah menjadi cokelat kuning, dengan tekstur yang lebih liat. Tanah jenis ini berlanjut hingga ke spit (5). Artefak tidak ditemukan di spit (3) sampai dengan akhir penggalian, yaitu spit (5). Temuan pada kotak TP 5 dapat dilihat pada Tabel 5 . 


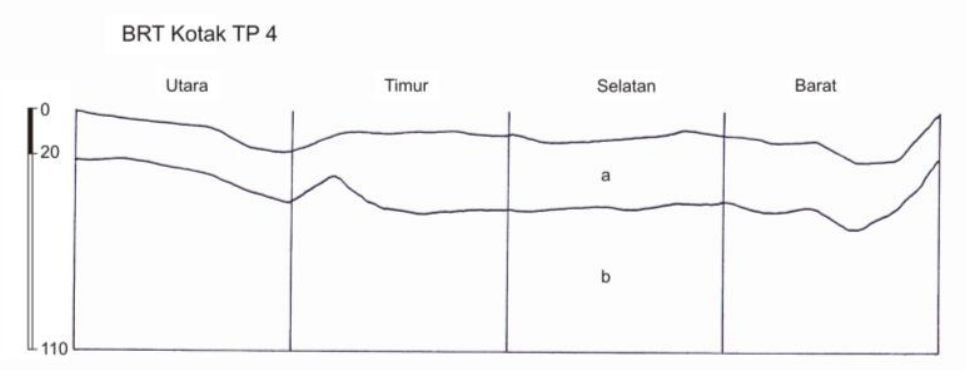

Keterangan Stratigrafi (Lapisan Tanah):

Lapisan a: Berwarna yellowish brown to dark yellowish brown hue 10 yr 5/6 - 4/6, ukuran lempung, sifat: gembur, lepas-lepas, banyak terdapat akar, nama: Lempung Coklat Susu Lapisan b: Warna yellow to brownish yellow hue 10 yr 7/8 - 6/8, ukuran butir lempung, sifat agak liat, nama: Lempung Coklat

BRT Kotak TP 5

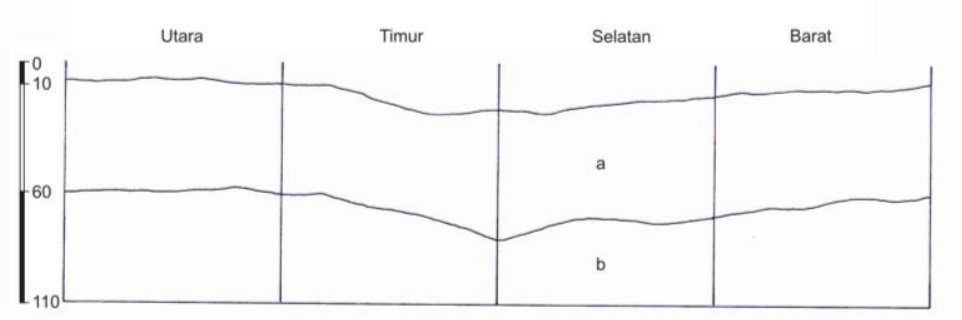

Keterangan Stratigrafi (Lapisan Tanah):

Lapisan a: Berwarna yellowish brown to dark yellowish brown hue 10 yr 5/6 - 4/6, ukuran butir lempung, sifat: gembur, lepas-lepas, banyak terdapat akar, nama: Lempung Coklat Susu

Lapisan b: Warna reddish yellow to strong brown hue 7.5 yr $6 / 8-5 / 8$, ukuran butir lempung, sifat liat, nama: Lempung Kuning Tua

Sumber: Dok. Balar Kalsel 2014

Gambar 6 Stratigrafi TP 4 dan TP 5

Spit (1) memiliki kedalaman $20 \mathrm{~cm}$, dan jarak interval antarspit adalah $20 \mathrm{~cm}$ (Gambar 6). Pada spit (1) ditemukan beberapa artefak, yang terdiri atas fragmen gerabah dan porselen dan Stoneware dengan jumlah yang tidak terlalu banyak. Warna tanah di spit ini abu-abu kehitaman dengan kandungan pasir yang lebih banyak dan gembur. Spit (2) masih memiliki jenis dan warna tanah yang sama. Menginjak spit yang ke-3, tanah berubah menjadi cokelat kuning, dengan tekstur yang lebih liat. Tanah jenis ini berlanjut hingga ke spit (5). Artefak tidak ditemukan di spit (3) sampai dengan akhir penggalian, yaitu spit (5). Temuan pada kotak TP 5 dapat dilihat pada Tabel 5.

Tabel 5 Temuan di TP 5

\begin{tabular}{|l|l|l|l|}
\hline No. & Spit & \multicolumn{1}{|c|}{ Jenis Temuan } & Jumlah \\
\hline 1 & $(\mathrm{p})$ & $\begin{array}{l}\text { Fragmen gerabah } \\
\text { (earthenware) }\end{array}$ & 4 \\
\hline & & Manik kaca warna biru & 1 \\
\hline & & Batu kuarsa & 1 \\
\hline
\end{tabular}

\begin{tabular}{|l|l|l|l|}
\hline No. & Spit & \multicolumn{1}{|c|}{ Jenis Temuan } & Jumlah \\
\hline & & Serpih rijang & 1 \\
\hline 2 & $(1)$ & Fragmen porselen & 6 \\
\hline 3 & $(2)$ & Fragmen porselen & 1 \\
\hline
\end{tabular}

Sumber : Hasil Penelitian 2014

\section{Hasil Analisis}

\section{Analisis Lingkungan}

Bukit Rayang mempunyai topografi yang tidak rata. Ada sekitar 5 kontur yang berbeda dari tepian sungai sampai dengan puncak bukit. Pada lereng bukit terdapat tanah yang rata. Letak bukit ini berada tepat di belokan Sungai Tayan yang tajam (sekitar $45^{\circ}$ ). Pada saat ini bukit sudah tidak dihuni oleh penduduk. Pemilihan lokasi pusat kerajaan ini berorientasi ke bukit. Desa terdekat yang berjarak sekitar $1 \mathrm{~km}$ adalah Desa Melugai. Bukit Rayang selain berada di tepi Sungai Tayan juga dialiri oleh Sungai Rayang yang juga memiliki anak sungai. Pada bagian belakang bukit terdapat 
sumber mata air yang dikenal dengan nama pemandian puteri. Mata air ini mengalir ke arah Sungai Tayan pada sisi bukit sebelah selatan. Dengan ketersediaan air bersih dan akses keluar melalui dua aliran sungai yang berbeda, lokasi bukit ini memang ideal untuk menjadi tempat tinggal. Letak bukit yang lebih tinggi dari wilayah di sekitarnya membuat pandangan mata leluasa mengarah ke aliran Sungai Tayan, baik ke arah hulu maupun ke arah hilir. Oleh karena itu, tempat ini juga ideal untuk pengintaian terhadap lalu lintas di Sungai Tayan.

Bukit Rayang merupakan topografi bukit terisolasi (isolated hill) yang terletak dalam kawasan perbukitan pada tepian Sungai Tayan. Bukit ini dikelilingi oleh beberapa aliran sungai yaitu Sungai Tayan di bagian mukanya, satu sungai kecil yang hanya teraliri selama musim penghujan berada di bagian hilir bukit dan satu sungai kecil yang selalu berair sepanjang tahun di bagian hulunya. Kelokan sungai pada bagian muka dari bukit ini merupakan bagian tepian sungai yang tergerus oleh air sungai pada morfologi sungai yang berkelok-kelok.

\section{Analisis Artefaktual}

Hasil analisis artefak yang dikumpulkan selama survei dapat dilihat pada Tabel 6 (fragmen porselen) dan Tabel 7 (fragmen gerabah). Fragmen porselen dengan bahan Stoneware dan porselen tersebut dari Cina Dinasti Qing (abad ke$20 \mathrm{M}$ ), dan produk lokal (Singkawang, abad ke-20 M). Wadah gerabah (berbahan earthenware) merupakan produk lokal. Fragmen artefak tersebut ditemukan di permukaan tanah yang tersebar di area tepian sungai.

Dari hasil ekskavasi pada lima kotak test pit didapatkan beberapa jenis artefak yang memiliki bahan yang berbeda. Hasil analisis terhadap temuan di kotak ekskavasi tersebut dapat dilihat pada Tabel 8 (fragmen porselen), Tabel 9 (fragmen gerabah), dan Tabel 10 (fragmen kaca).Jumlah temuan fragmen yang paling banyak adalah fragmen porselen yang berasal dari Cina (Dinasti Ming Akhir, Qing, dan modern), Asia Tenggara, Eropa dan juga produk lokal. Fragmen dari gerabah ditemukan dalam bentuk wadah terbuka (mangkuk), wadah tertutup (tempayan) dengan jumlah fragmen lebih sedikit daripada temuan fragmen porselen. Fragmen kaca berasal dari bentuk botol bulat dan kotak dengan warna yang beragam.

Dari lima lokasi test pit di Bukit Rayang, TP 1 yang diperkirakan sebagai tempat berdirinya bangunan keraton/istana (di depan benteng tanah) ditemukan jumlah fragmen porselen yang paling banyak dan juga menjadi tes pit yang memiliki ragam temuan paling lengkap dibandingkan dengan test pit lainnya. Sebaliknya, di lokasi TP 5 hanya fragmen gerabah yang ditemukan tanpa ada temuan fragmen porselen.

Hasil analisis artefaktual memberi gambaran hunian di situs Bukit Rayang sudah kompleks, dan temuan porselen Cina dari masa Ming Akhir, baik dari hasil survei maupun ekskavasi. Sesuai dengan data sejarah yang menyebutkan bahwa bukit ini digunakan oleh Gusti Lekar pada akhir abad ke-17 Masehi. Kronologi pendirian Kerajaan Tayan pada tahun 1687 cocok dengan fragmen porselen Cina, tipisnya lapisan budaya memberi petunjuk singkatnya lama hunian, banyak artefak ditemukan pada spit (1) dan (2) yang merupakan satu lapisan budaya yang berada di bagian paling atas. Jumlah fragmen porselen Cina terbanyak adalah wadah dari Dinasti Qing (abad ke 18-20 M), dan fragmen porselen Eropa yang berasal dari abad ke 19-20 M.

Selanjutnya, ketika pusat kekuasaan Tayan dipindahkan ke arah hilir, bukit tersebut tidak langsung ditinggalkan, tetapi tetap digunakan, terutama di wilayah sekitar temuan meriam (TP 3) banyak ditemukan fragmen kaca dan peralatan dari besi. Demikian juga dengan aktivitas penguburan tetap berlangsung di tempat tersebut hingga sekarang, ketika Bukit Rayang tidak lagi dimanfaatkan sebagai tempat tinggal. Ahli waris untuk saat ini ada yang bertempat tinggal di Desa Melugai, yang juga memanfaatkan area di Bukit Rayang sebagai bagian dari ladang mereka.

Kotak ekskavasi pada penelitian ini memiliki ketinggian yang berbeda, lokasi tempat tinggal berada di bagian bukit dekat dengan tepian sungai, bukan di puncaknya. Kedudukan TP 3 berada di bagian paling jauh dan terendah dibandingkan dengan kotak lainnya. Bagian puncak bukit digunakan untuk membangun benteng tanah. Dilihat dari segi lingkungannya, letak Bukit Rayang sangat strategis, yaitu di belokan sungai, sangat memudahkan untuk melihat ke arah hilir dan hulu. Kondisi yang menguntungkan untuk mengawasi 
Ialu lintas sungai, dan siapapun yang melintas. Situasi keamanan di wilayah tersebut yang tidak stabil menjadi pertimbangan utama diperlukannya bangunan benteng. Selain itu, keberadaan benteng tampaknya juga berkaitan erat dengan tugas Gusti lekar di wilayah tersebut yang diperintahkan untuk mengamankan upeti dari wilayah hulu Sungai Tayan.

\section{PENUTUP}

Penelitian awal di situs Bukit Rayang menghasilkan data arkeologi berupa benteng tanah, bekas pemandian putri, tonggak bekas jembatan, makam kerabat istana, tonggak bekas masjid, bekas pendapa, meriam, dan artefak berupa fragmen dari bahan yang beragam (tanah liat, Stoneware, porselen, kaca, logam, dan batu). Data tersebut menggambarkan kehidupan masyarakat sudah sangat kompleks pada abad ke17 hingga $20 \mathrm{M}$.

Alasan memilih tempat ini sebagai pusat kekuasaan karena strategis, lingkungannya mendukung dan telah dimanfaatkan sesuai dengan kebutuhan. Hal tersebut tampak dari sebaran artefak yang merupakan sisa aktivitas hunian yang ditemukan kembali melalui kegiatan survei dan ekskavasi, juga adanya beberapa titik bangunan pendukung kehidupan kelompok masyarakat di tempat tersebut. Tempat yang paling tinggi terdapat bangunan benteng. Bentuk benteng dapat diketahui dari penelitian ini, demikian pula dengan sebaran hunian yang ada di sekitarnya. Bukit ini juga dikelilingi oleh sungai sebagai akses untuk melarikan diri bila terjadi serangan dari musuh.

Meskipun demikian masih ada beberapa hal yang belum diketahui, seperti aktivitas apa yang dilakukan di dalam benteng (letak istana berada di luar benteng), sehingga masih diperlukan ekskavasi di dalam benteng tanah. Selain itu, keberadaan masjid yang lokasinya tidak berada di bukit, tetapi di seberangnya (dibatasi oleh sungai) sangat menarik sehingga perlu dilakukan survei dan ekskavasi di lokasi masjid dan sekitarnya.

\section{UCAPAN TERIMA KASIH}

Ucapan terima kasih ditujukan kepada Tim penelitian Balai Arkeologi Kalimantan Selatan (2014) yang diketuai oleh Bapak Bambang Sakti Wiku Atomojo, kepada pihak Keraton Pakunegoro Tayan, yaitu Raja Tayan Bapak Yusryansyah dan Ratu Tayan Ibu Hariyani yang telah membantu dan memfasilitasi kegiatan ekskavasi di Bukit Rayang, dan juga aparat desa dan masyarakat Desa Melugai, Sanggau.

\section{DAFTAR PUSTAKA}

Andi, Uray Fery. 2017. "Pengaruh Jaringan Perdagangan Global Pada Struktur Wilayah Dan Konfigurasi Spasial Pusat Pemerintahan Kesultanan-Kesultanan Melayu Di Kalimantan Barat." Langkau Betang: Jurnal Arsitektur IV(1):67--78.

Atmojo, Bambang Sakti Wiku. 2014. "Penelitian Situs Bangunan Bata Negeri Baru, Kabupaten Ketapang, Kalimantan Barat." Berita Penelitian Arkeologi 8:1--72.

Branton, Nicole. 2009. "Landscape Approaches in Historical Archaeology: The Archaeology of Places." Pp. 51-65 in International Handbook of Historical Archaeology, edited by $\mathrm{T}$. Majewski and D. Gaimster. Springer Science and Business Media.

Cahyaningtyas, Yuka Nurtanti. 2013. "Lingkungan 82
Pengendapan Di Situs Negeri Baru, Kalimantan Barat." Naditira Widya 7(1):26-43.

Gojda, M. 2004. "Landscape Archaeology." Pp. 198--226 in Archaeology. Vol. I. Oxford-UK: Encyclopedia of Life Support Systems (EOLSS)-UNESCO.

Kusnoto, Yuver and Haris Firmansyah. 2016. "Eksistensi Istana Kerajaan Di Kalimantan Barat Sebgai Sumber Belajar Sejarah." Jurnal Historia 4(1):19-- 28.

Purmintasari, Yulita Dewi and Yuver Kusnoto. 2018. "Pemukiman Awal Sungai Kapuas." SOCIA: Jurnal IImu-IImu Sosial 15(1):71-78.

Renfrew, Colin dan and Paul G. Bahn. 2012. Archaeology Theories, Methodes and Practice. London: Thames and Hudson. 
Sarjiyanto, Sarjiyanto and Libra Hari Inagurasi. 2018. "Perdagangan Di Pertemuan Sungai Kapuas Dan Tayan, Sanggau, Kalimantan Barat, Abad Ke-19." PURBAWIDYA: Jurnal Penelitian Dan Pengembangan Arkeologi 7(1):71-- 88.

Sellato, Bernard. 2015. 'Sultans' Palaces and Museums in Indonesian Borneo: National Policies, Political Decentralization, Cultural Depatrimonization, Identity Relocalization, 1950-2010." Archipel 89:125-60.
Sitio, Johan Moryanto. 2018. "Penataan Kawasan Keraton Pakunegara Tayan." Jurnal Online Mahasiswa Arsitektur Universitas Tanjungpura 6(2):400-414.

Smith, F. A. and H. F. Smith. 2011. "A Shadowy State in Borneo: Where Was Tanjungpura?" Borneo Research Bulletin 42(89-103).

Supriatna, S, Margono, U, Sutrisno, Pieters, P.E, Langford, R. .. 1993. Peta Geologi Lembar Sanggau, Kalimantan. Bandung: Pusat Penelitian dan Pengembangan Geologi. 
Tabel 6 Hasil Analisis Temuan Keramik Survei

\begin{tabular}{|l|l|l|l|l|l|l|}
\hline No. & Bahan/bentuk & Jenis/jumlah & Glasir & Motif hias & Periodisasi & Ket \\
\hline 1 & Stoneware/pasu & Tepian/2 & $\begin{array}{l}\text { Bagian luar } \\
\text { cokelat, glasir } \\
\text { bagian dalam } \\
\text { hijau }\end{array}$ & polos & Qing (abad ke-20 M) & \\
\hline 2 & Stoneware/tempayan & Tepian/1 & Glasir cokelat & $\begin{array}{l}\text { Hias gores garis } \\
\text { gelombang }\end{array}$ & Qing (abad ke-20 M) & polos \\
\hline 3 & Stoneware/pasu & $\begin{array}{l}\text { Tutup/1; } \\
\text { tepian/1; } \\
\text { badan/2 }\end{array}$ & Glasir hijau & Qing (abad ke-20 M) & \\
\hline 4 & Stoneware/wadah & Badan/2 & Glasir cokelat & polos & Lokal (abad ke-20 M) & \\
\hline 5 & Porselen/piring & $\begin{array}{l}\text { Tepian/4; } \\
\text { badan/9 }\end{array}$ & $\begin{array}{l}\text { Glasir putih, } \\
\text { pecah seribu }\end{array}$ & polos & Modern (abad ke-21 M) & \\
\hline 6 & Stoneware/periuk & Tepian/2 & Glasir hijau & polos & Lokal (abad ke-20 M) & Lokal (abad ke-20 M) \\
\hline 7 & Stoneware/periuk & Badan/1 & Glasir cokelat & polos & Lokal (abad ke-20 M) & Bahan abu-abu \\
\hline 8 & $\begin{array}{l}\text { Stoneware/kendi?atau } \\
\text { teko? }\end{array}$ & $\begin{array}{l}\text { Pegangan/1; } \\
\text { dasar/3; } \\
\text { badan/6 }\end{array}$ & Tanpa glasir & polos & & \\
\hline
\end{tabular}

Sumber : hasil penelitian 2014

Tabel 7 Hasil Analisis Temuan Gerabah Survei

\begin{tabular}{|l|l|l|l|l|}
\hline No. & \multicolumn{1}{|c|}{ Bahan/bentuk } & \multicolumn{1}{|c|}{ Jenis/jumlah } & \multicolumn{1}{|c|}{ Motif hias } & \multicolumn{1}{|c|}{ Keterangan } \\
\hline 1 & Earthenware/wadah & Badan/2 & Hias gores garis mendatar & \\
\hline 2 & Earthenware/wadah & Badan/23 & Polos & $\begin{array}{l}\text { Bibir lurus, warna rata, merah } \\
\text { kuning }\end{array}$ \\
\hline 3 & Earthenware/pasu & $\begin{array}{l}\text { Tepian/2; } \\
\text { badan/2 }\end{array}$ & Polos & $\begin{array}{l}\text { Bentuk tepian berbeda, yaitu } \\
\text { melebar keluar, tebal melebar } \\
\text { keluar, dan kecil }\end{array}$ \\
\hline 4 & Earthenware/periuk & Tepian/3; & Polos & \\
\hline 6 & Earthenware/periuk & Tepian/1 & $\begin{array}{l}\text { Berhias dengan teknik pijit, } \\
\text { membentuk gelombang }\end{array}$ & $\begin{array}{l}\text { Diameter } 3 \text { cm dengan bentu } \\
\text { bulat tinggi }\end{array}$ \\
\hline 7 & Earthenware/wadah & Dasar/1 & Polos & Warna krem \\
\hline
\end{tabular}

Sumber : hasil penelitian 2014

Tabel 8 Hasil Analisis Temuan Fragmen Keramik Ekskavasi

\begin{tabular}{|c|c|c|c|c|c|c|c|}
\hline No. & Kotak/spit & Bahan/bentuk & Jenis/jumlah & Glasir & Motif hias & periodisasi & Ket \\
\hline \multirow[t]{4}{*}{1} & TP $1 / p$ & Porselen/mangkuk (?) & Badan/5 & $\begin{array}{l}\text { Underglazed biru } \\
\text { putih }\end{array}$ & $\begin{array}{l}\text { Geometris, } \\
\text { flora }\end{array}$ & $\begin{array}{l}\text { Qing, abad } \\
\text { ke-18-20 } \\
M\end{array}$ & \\
\hline & & Porselen/sendok & Tepian/4 & $\begin{array}{l}\text { Underglazed biru } \\
\text { putih }\end{array}$ & $\begin{array}{l}\text { Geometris, } \\
\text { flora }\end{array}$ & $\begin{array}{l}\text { Qing, abad } \\
\text { ke-18-20 M }\end{array}$ & \\
\hline & & Porselen/wadah & Badan/4 & -sda- & $\begin{array}{l}\text { Geometris,fl } \\
\text { ora }\end{array}$ & $\begin{array}{l}\text { Qing, abad } \\
\text { ke-18-20 } \\
M\end{array}$ & \\
\hline & & Porselen/mangkuk & Dasar/1 & $\begin{array}{l}\text { Underglazed biru } \\
\text { putih, } \\
\text { upperglazed hijau }\end{array}$ & Geometris & $\begin{array}{l}\text { Ming akhir, } \\
\text { abad ke-17 } \\
\text { M }\end{array}$ & \\
\hline
\end{tabular}




\begin{tabular}{|c|c|c|c|c|c|c|c|}
\hline No. & Kotak/spit & Bahan/bentuk & Jenis/jumlah & Glasir & Motif hias & periodisasi & Ket \\
\hline & & Porselen/mangkuk & Tepian/1 & $\begin{array}{l}\text { Seladon, glasir } \\
\text { hijau }\end{array}$ & Polos & $\begin{array}{l}\text { Yuan, abad } \\
\text { ke-13-15 M } \\
\text { (?) }\end{array}$ & \\
\hline & & Porselen/wadah & Badan/4 & Glasir hijau, tipis & Polos & $\begin{array}{l}\text { Qing, abad } \\
\text { ke-18-20 M }\end{array}$ & \\
\hline & & Porselen/mangkuk & Tepian/2 & Glasir hijau, tipis & Polos & $\begin{array}{l}\text { Qing, abad } \\
\text { ke-18-20 M }\end{array}$ & \\
\hline & & Porselen/wadah & Badan/9 & Glasir hijau, tipis & Polos & Thailand (?) & $\begin{array}{l}\text { Bahan abu- } \\
\text { abu }\end{array}$ \\
\hline & & Porselen/wadah & Badan/1 & $\begin{array}{l}\text { Glasir putih pecah } \\
\text { seribu }\end{array}$ & Polos & $\begin{array}{l}\text { Thailand/Vie } \\
\text { t-nam }\end{array}$ & $\begin{array}{l}\text { Bahan } \\
\text { cokelat }\end{array}$ \\
\hline & & Stoneware/tempayan & Badan/1 & Glasir hijau & Polos & $\begin{array}{l}\text { Qing, abad } \\
\text { ke-20 M }\end{array}$ & \\
\hline & & Stoneware/tempayan & Dasar/4 & Tanpa glasir & Polos & $\begin{array}{l}\text { Qing, abad } \\
\text { ke-20 M }\end{array}$ & \\
\hline & & Stoneware/mangkuk & Tepian/ 1 & Tanpa glasir & Polos & $\begin{array}{l}\text { Asia } \\
\text { Tenggara } \\
(?)\end{array}$ & Tipis \\
\hline & & Porselen/piring & Dasar cincin/4 & $\begin{array}{l}\text { Underglazed biru } \\
\text { putih }\end{array}$ & $\begin{array}{l}\text { Rumah, } \\
\text { pemandang } \\
\text { an, } \\
\text { geometris }\end{array}$ & $\begin{array}{l}\text { Eropa, abad } \\
\text { ke-20 M }\end{array}$ & \\
\hline & & Porselen/piring & Tepian/5 & $\begin{array}{l}\text { Underglazed biru } \\
\text { putih }\end{array}$ & $\begin{array}{l}\text { Hias } \\
\text { geometris }\end{array}$ & $\begin{array}{l}\text { Eropa, abad } \\
\text { ke-20 M }\end{array}$ & \\
\hline & & Porselen/piring & Badan/2 & $\begin{array}{l}\text { Underglazed } \\
\text { merah putih }\end{array}$ & Hias flora & $\begin{array}{l}\text { Eropa, abad } \\
\text { ke- } 20 \mathrm{M}\end{array}$ & \\
\hline & & Porselen/mangkuk & Badan/2 & $\begin{array}{l}\text { Underglazed hijau } \\
\text { putih }\end{array}$ & $\begin{array}{l}\text { Hias } \\
\text { geometris }\end{array}$ & $\begin{array}{l}\text { Eropa, abad } \\
\text { ke- } 20 \mathrm{M}\end{array}$ & \\
\hline & & Porselen/piring & Tepian/3 & $\begin{array}{l}\text { Underglazed biru } \\
\text { putih }\end{array}$ & $\begin{array}{l}\text { Garis biru di } \\
\text { ujung }\end{array}$ & $\begin{array}{l}\text { Modern, } \\
\text { abad ke-21 } \\
\text { M }\end{array}$ & \\
\hline & & Porselen/piring & Badan/1 & Polikrom & & $\begin{array}{l}\text { Eropa, abad } \\
\text { ke- } 20 \mathrm{M}\end{array}$ & \\
\hline & 1 & Porselen/sendok & Tepian/6 & $\begin{array}{l}\text { Underglazed biru } \\
\text { putih }\end{array}$ & $\begin{array}{l}\text { Flora, } \\
\text { geometris }\end{array}$ & $\begin{array}{l}\text { Qing, abad } \\
\text { ke-18-20 M }\end{array}$ & \\
\hline & & Porselen/wadah & Badan/21 & $\begin{array}{l}\text { Underglazed biru } \\
\text { putih }\end{array}$ & $\begin{array}{l}\text { Geometris, } \\
\text { flora }\end{array}$ & $\begin{array}{l}\text { Qing, abad } \\
\text { ke-18-20 M }\end{array}$ & \\
\hline & & Porselen/mangkuk & Tepian/14 & $\begin{array}{l}\text { Underglazed biru } \\
\text { putih }\end{array}$ & $\begin{array}{l}\text { Geometris } \\
\text { (garis, } \\
\text { lengkung, } \\
\text { ukel) }\end{array}$ & $\begin{array}{l}\text { Qing, abad } \\
\text { ke -18-20 M }\end{array}$ & \\
\hline & & Porselen/piring & Tepian/11 & $\begin{array}{l}\text { Underglazed biru } \\
\text { putih }\end{array}$ & $\begin{array}{l}\text { Geometris } \\
\text { (garis, } \\
\text { lengkung, } \\
\text { ukel) }\end{array}$ & $\begin{array}{l}\text { Qing, abad } \\
\text { ke-18-20 M }\end{array}$ & \\
\hline & & Porselen/piring & Tepian/3 & $\begin{array}{l}\text { Glasir } \\
\text { hijau/seladon }\end{array}$ & Polos & $\begin{array}{l}\text { Qing, abad } \\
\text { ke-18-20 M }\end{array}$ & \\
\hline & & Porselen/cepuk & Tepian/2 & $\begin{array}{l}\text { Underglazed biru } \\
\text { putih }\end{array}$ & $\begin{array}{l}\text { Flora dan } \\
\text { geometris } \\
\text { (garis) }\end{array}$ & $\begin{array}{l}\text { Qing, abad } \\
\text { ke-18-20 M }\end{array}$ & \\
\hline & & Porselen/mangkuk & $\begin{array}{l}\text { Tepian/2, } \\
\text { badan/1 }\end{array}$ & $\begin{array}{l}\text { Upperglazed putih } \\
\text { merah }\end{array}$ & Flora (?) & $\begin{array}{l}\text { Ming Akhir, } \\
\text { abad ke-17- } \\
18 \mathrm{M}\end{array}$ & \\
\hline & & $\begin{array}{l}\text { Porselen/dish(piring } \\
\text { besar) }\end{array}$ & Dasar/2 & $\begin{array}{l}\text { Underglazed biru } \\
\text { putih }\end{array}$ & Geometris & $\begin{array}{l}\text { Qing, abad } \\
\text { ke-18-20 M }\end{array}$ & $\begin{array}{l}\text { Dasar } \\
\text { bentuk } \\
\text { cincin } \\
\end{array}$ \\
\hline & & Porselen/mangkuk & Dasar/1 & Glasir putih & Polos & Qing, abad & Dasar betuk \\
\hline
\end{tabular}


Pusat Kerajaan Tayan di Bukit Rayang, Sanggau, Kalimantan Barat-Sunarningsih dan Yuka Nurtanti Cahyaningtyas (73-90) Doi: 10.24832/ke.v7i2.102

\begin{tabular}{|c|c|c|c|c|c|c|c|}
\hline No. & Kotak/spit & Bahan/bentuk & Jenis/jumlah & Glasir & Motif hias & periodisasi & Ket \\
\hline & & & & & & ke-18-20 M & cincin \\
\hline & & Porselen/mangkuk & Tepian/1 & $\begin{array}{l}\text { Glasir hijau } \\
\text { seladon }\end{array}$ & Polos & $\begin{array}{l}\text { Yuan (?), } \\
\text { abad ke-13- } \\
14 \mathrm{M}\end{array}$ & \\
\hline & & Porselen/mangkuk & Tepian/1 & $\begin{array}{l}\text { Underglazed biru } \\
\text { putih }\end{array}$ & Abstrak & $\begin{array}{l}\text { Modern, } \\
\text { abad ke-20 } \\
\text { M }\end{array}$ & \\
\hline & & Porselen/dish & $\begin{array}{l}\text { Dasar/2; } \\
\text { tepian/3; } \\
\text { badan/3 }\end{array}$ & $\begin{array}{l}\text { Underglazed biru } \\
\text { putih }\end{array}$ & $\begin{array}{l}\text { Pemandang } \\
\text { an }\end{array}$ & $\begin{array}{l}\text { Eropa, abad } \\
\text { ke-20 M }\end{array}$ & $\begin{array}{l}\text { Bentuk } \\
\text { dasar cincin } \\
\text { rendah }\end{array}$ \\
\hline & & Porselen/piring & Badan/2 & $\begin{array}{l}\text { Glasir putih biru } \\
\text { muda (kabur) }\end{array}$ & Geometris & $\begin{array}{l}\text { Eropa, abad } \\
\text { ke- } 20 \mathrm{M}\end{array}$ & \\
\hline & & Porselen/wadah & Badan/1 & Glasir putih ungu & $\begin{array}{l}\text { Buah- } \\
\text { buahan }\end{array}$ & $\begin{array}{l}\text { Eropa, abad } \\
\text { ke-20 M }\end{array}$ & \\
\hline & & Porselen/piring & Tepian/3 & Glasir biru putih & $\begin{array}{l}\text { Bunga dan } \\
\text { geometris }\end{array}$ & $\begin{array}{l}\text { Eropa, abad } \\
\text { ke-20 M }\end{array}$ & \\
\hline & & Porselen/mangkuk & Tepian/3 & Glasir biru putih & & $\begin{array}{l}\text { Eropa, abad } \\
\text { ke-20 M }\end{array}$ & \\
\hline & & Porselen/wadah & Badan $/ 5$ & Glasir putih merah & & $\begin{array}{l}\text { Eropa, abad } \\
\text { ke-20 M }\end{array}$ & \\
\hline & & Porselen/wadah & Badan/8 & $\begin{array}{l}\text { Glasir putih pecah } \\
\text { seribu }\end{array}$ & Polos & $\begin{array}{l}\text { Eropa, abad } \\
\text { ke- } 20 \mathrm{M}\end{array}$ & \\
\hline & & Porselen/wadah & Badan/1 & Glasir hijau putih & $\begin{array}{l}\text { Pemandang } \\
\text { an (rumah) }\end{array}$ & $\begin{array}{l}\text { Eropa, abad } \\
\text { ke-20 M }\end{array}$ & \\
\hline & & Porselen/wadah & Dasar/1 & $\begin{array}{l}\text { Glasir putih pecah } \\
\text { seribu }\end{array}$ & Polos & $\begin{array}{l}\text { Eropa, abad } \\
\text { ke- } 20 \mathrm{M}\end{array}$ & \\
\hline & & Porselen/piring & Tepian/1 & Glasir biru putih & Garis biru & $\begin{array}{l}\text { Eropa, abad } \\
\text { ke-20 M }\end{array}$ & \\
\hline & & Stoneware/guci & $\begin{array}{l}\text { Dasar/2; } \\
\text { badan } 16\end{array}$ & Tanpa glasir & Polos & Lokal (?) & $\begin{array}{l}\text { Dasar rata, } \\
\text { Stoneware } \\
\text { tipis }\end{array}$ \\
\hline & & Stoneware/guci & $\begin{array}{l}\text { Dasar/3; } \\
\text { badan } 3\end{array}$ & Glasir cokelat tua & Polos & Lokal (?) & $\begin{array}{l}\text { Dasar rata, } \\
\text { Stoneware } \\
\text { tipis }\end{array}$ \\
\hline & & Stoneware/guci & dasar/3 & Glasir putih & Polos & Lokal (?) & $\begin{array}{l}\text { Dasar rata } 2 \\
\text { buah, dasar } \\
\text { cincin tinggi } \\
1 \text { buah }\end{array}$ \\
\hline & & Stoneware/wadah & Badan/1 & Glasir cokelat & Geometris & Lokal (?) & \\
\hline & & Stoneware/guci & $\begin{array}{l}\text { Badan/1; } \\
\text { dasar/1; } \\
\text { tepian/1 }\end{array}$ & Glasir hijau & Polos & $\begin{array}{l}\text { Qing, abad } \\
\text { ke-20 M }\end{array}$ & Dasar rata \\
\hline & & Stoneware/piring kecil & Tepian/3 & Tanpa glasir & Polos & $\begin{array}{l}\text { Modern, } \\
\text { abad ke-21 } \\
M\end{array}$ & \\
\hline & & Stoneware/mangkuk & Tepian/1 & Tanpa glasir & & $\begin{array}{l}\text { Lokal, abad } \\
\text { ke-20 M }\end{array}$ & $\begin{array}{l}\text { Bentuk } \\
\text { tepian tebal, } \\
\text { terlipat ke } \\
\text { luar }\end{array}$ \\
\hline & & Stoneware/wadah & Badan/1 & Glasir hijau & Polos & $\begin{array}{l}\text { Qing, abad } \\
\text { ke-18-20 M }\end{array}$ & \\
\hline & 2 & Porselen/mangkuk & Tepian/2 & $\begin{array}{l}\text { Underglazed biru } \\
\text { putih }\end{array}$ & $\begin{array}{l}\text { Geometris, } \\
\text { flora }\end{array}$ & $\begin{array}{l}\text { Qing, abad } \\
\text { ke-18-20 M }\end{array}$ & \\
\hline & & Porselen/cepuk & Tepian/1 & $\begin{array}{l}\text { Underglazed biru } \\
\text { putih }\end{array}$ & $\begin{array}{l}\text { Geometris, } \\
\text { flora }\end{array}$ & $\begin{array}{l}\text { Qing, abad } \\
\text { ke-18-20 M }\end{array}$ & \\
\hline & & Porselen/piring & Tepian/1 & $\begin{array}{l}\text { Underglazed biru } \\
\text { putih }\end{array}$ & Geometris & $\begin{array}{l}\text { Eropa, abad } \\
\text { ke-20 M }\end{array}$ & \\
\hline
\end{tabular}




\begin{tabular}{|c|c|c|c|c|c|c|c|}
\hline No. & Kotak/spit & Bahan/bentuk & Jenis/jumlah & Glasir & Motif hias & periodisasi & Ket \\
\hline & & $\begin{array}{l}\text { Stoneware/wadah } \\
\text { kaki tinggi }\end{array}$ & Dasar/4 & Glasir hijau & Polos & $\begin{array}{l}\text { Qing, abad } \\
\text { ke-18-20 M }\end{array}$ & \\
\hline & & Porselen/wadah & Badan/1 & $\begin{array}{l}\text { Glasir putih } \\
\text { kehijuan (seladon) }\end{array}$ & Polos & Qing (?) & \\
\hline \multirow[t]{19}{*}{2} & TP $2 / p$ & Porselen/piring & $\begin{array}{l}\text { Badan/1; } \\
\text { tepian/1 }\end{array}$ & $\begin{array}{l}\text { Glasir putih pecah } \\
\text { seribu }\end{array}$ & $\begin{array}{l}\text { Polos, } \\
\text { hanya ada } \\
\text { tulisan } \\
\text { made in } \\
\text { Japan di } \\
\text { bagian } \\
\text { dasar }\end{array}$ & $\begin{array}{l}\text { Jepang, } \\
\text { modern, } \\
\text { abad ke-20 } \\
\text { M }\end{array}$ & \\
\hline & & Porselen/cangkir & Tepian/2 & Glasir putih & Bunga & $\begin{array}{l}\text { RRC, } \\
\text { modern, } \\
\text { abad ke-20 } \\
M\end{array}$ & \\
\hline & & Stoneware/wadah & Dasar/1 & $\begin{array}{l}\text { Glasir cokelat, di } \\
\text { bagian dalam }\end{array}$ & Polos & Lokal (?) & $\begin{array}{l}\text { Bagian } \\
\text { dasar } \\
\text { bentuk } \\
\text { cincin }\end{array}$ \\
\hline & & Porselen/piring & $\begin{array}{l}\text { Tepian } / 4 ; \\
\text { dasar } / 1\end{array}$ & $\begin{array}{l}\text { Underglazed biru } \\
\text { putih }\end{array}$ & Garis biru & $\begin{array}{l}\text { Eropa, abad } \\
\text { ke-20 M }\end{array}$ & $\begin{array}{l}\text { Pecah } \\
\text { seribu }\end{array}$ \\
\hline & & Porselen/piring & $\begin{array}{l}\text { Dasar/3; } \\
\text { tepian/1; } \\
\text { badan/4 }\end{array}$ & $\begin{array}{l}\text { Glasir putih pecah } \\
\text { seribu }\end{array}$ & Polos & $\begin{array}{l}\text { Eropa, abad } \\
\text { ke-20 M }\end{array}$ & \\
\hline & & Porselen/wadah & Badan/2 & $\begin{array}{l}\text { Underglazed biru } \\
\text { putih }\end{array}$ & & $\begin{array}{l}\text { Qing, abad } \\
\text { ke-18-20 M }\end{array}$ & \\
\hline & 1 & Stoneware/kendi & Cucuk/1 & Tanpa glasir & Polos & $\begin{array}{l}\text { Lokal, abad } \\
\text { ke-20 M }\end{array}$ & $\begin{array}{l}\text { Bahan } \\
\text { berwarna } \\
\text { cokelat }\end{array}$ \\
\hline & & Stoneware/guci & $\begin{array}{l}\text { Tepian/1; } \\
\text { badan/2 }\end{array}$ & Tanpa glasir & Polos & $\begin{array}{l}\text { Lokal, abad } \\
\text { ke- } 20 \mathrm{M}\end{array}$ & \\
\hline & & Stoneware/guci & Badan/1 & Glasir hijau & Polos & $\begin{array}{l}\text { Qing, abad } \\
\text { ke-18-20 M }\end{array}$ & \\
\hline & & Stoneware/guci & Badan/1 & Glasir cokelat & Polos & $\begin{array}{l}\text { Lokal, abad } \\
\text { ke- } 20 \mathrm{M}\end{array}$ & \\
\hline & & Porselen/wadah & Badan/1 & $\begin{array}{l}\text { Underglazed biru } \\
\text { putih }\end{array}$ & $\begin{array}{l}\text { Motif } \\
\text { geometris }\end{array}$ & $\begin{array}{l}\text { Qing, abad } \\
\text { ke-18-20 M }\end{array}$ & \\
\hline & & Porselen/cangkir & Pegangan/1 & Glasir putih & Polos & $\begin{array}{l}\text { Modern, } \\
\text { abad ke-21 } \\
\text { M }\end{array}$ & \\
\hline & & Porselen/cangkir & Pegangan/1 & $\begin{array}{l}\text { Glasir putih pecah } \\
\text { seribu }\end{array}$ & Polos & $\begin{array}{l}\text { Eropa abad } \\
\text { ke- } 20 \mathrm{M}\end{array}$ & \\
\hline & & Porselen/sendok & Pegangan/1 & Glasir putih & Polos & $\begin{array}{l}\text { Eropa, abad } \\
\text { ke-20 M }\end{array}$ & \\
\hline & & Porselen/mangkuk & $\begin{array}{l}\text { Tepia/5; } \\
\text { dasar/2; } \\
\text { badan/6 }\end{array}$ & $\begin{array}{l}\text { Underglazed putih } \\
\text { biru }\end{array}$ & $\begin{array}{l}\text { Geometris } \\
\text { dan bunga }\end{array}$ & $\begin{array}{l}\text { Qing, abad } \\
\text { ke-18-20 M }\end{array}$ & \\
\hline & & Porselen/piring & $\begin{array}{l}\text { Tepian/5; } \\
\text { badan/9 }\end{array}$ & $\begin{array}{l}\text { Glasir putih, } \\
\text { pecah seribu }\end{array}$ & Polos & $\begin{array}{l}\text { Eropa, abad } \\
\text { ke-20 M }\end{array}$ & \\
\hline & & Porselen/piring & $\begin{array}{l}\text { Tepian/1; } \\
\text { badan/1 }\end{array}$ & $\begin{array}{l}\text { Glasir putih } \\
\text { merah, pecah } \\
\text { seribu }\end{array}$ & Flora & $\begin{array}{l}\text { Eropa, abad } \\
\text { ke-20 M }\end{array}$ & \\
\hline & & Porselen/piring & Badan/1 & $\begin{array}{l}\text { Glasir putih hijau, } \\
\text { pecah seribu }\end{array}$ & Flora & $\begin{array}{l}\text { Eropa, abad } \\
\text { ke-20 M }\end{array}$ & \\
\hline & & Porselen/piring kecil & $\begin{array}{l}\text { Tepian } / 4 \\
\text { badan } / 1\end{array}$ & $\begin{array}{l}\text { Glasir putih, } \\
\text { pecah seribu }\end{array}$ & Polos & $\begin{array}{l}\text { Modern, } \\
\text { abad ke-21 } \\
\text { M }\end{array}$ & \\
\hline
\end{tabular}


Pusat Kerajaan Tayan di Bukit Rayang, Sanggau, Kalimantan Barat-Sunarningsih dan Yuka Nurtanti Cahyaningtyas (73-90) Doi: $10.24832 /$ ke.v7i2.102

\begin{tabular}{|c|c|c|c|c|c|c|c|}
\hline No. & Kotak/spit & Bahan/bentuk & Jenis/jumlah & Glasir & Motif hias & periodisasi & Ket \\
\hline \multirow[t]{20}{*}{3} & TP 3/p & $\begin{array}{l}\text { Porselen/tutup } \\
\text { mangkuk }\end{array}$ & Tutup/1 & $\begin{array}{l}\text { Underglazed biru } \\
\text { putih }\end{array}$ & $\begin{array}{l}\text { Geometris, } \\
\text { flora }\end{array}$ & $\begin{array}{l}\text { Ming Akhir, } \\
\text { abad ke-17- } \\
18 \mathrm{M}\end{array}$ & \\
\hline & & Porselen/manguk & Tepian/2 & $\begin{array}{l}\text { Underglazed biru } \\
\text { puth }\end{array}$ & Geometris & $\begin{array}{l}\text { Qing, abad } \\
\text { ke-18 -20 M }\end{array}$ & \\
\hline & & Porselen/mangkuk & $\begin{array}{l}\text { Dasar/1; } \\
\text { badan/3 }\end{array}$ & $\begin{array}{l}\text { Glasir hijau, } \\
\text { seladon }\end{array}$ & Polos & $\begin{array}{l}\text { Qing, abad } \\
\text { ke-18-20 M }\end{array}$ & \\
\hline & & Porselen/piring & $\begin{array}{l}\text { Dasar/1; } \\
\text { tepian/4; } \\
\text { badan/5 }\end{array}$ & $\begin{array}{l}\text { Underglazed biru } \\
\text { putih }\end{array}$ & $\begin{array}{l}\text { Geometris, } \\
\text { flora }\end{array}$ & $\begin{array}{l}\text { Qing, abad } \\
\text { ke-18-20 M }\end{array}$ & \\
\hline & & Porselen/mangkuk & Tepian/1 & $\begin{array}{l}\text { Underglazed biru } \\
\text { putih }\end{array}$ & $\begin{array}{l}\text { Geometris } \\
\text { berupa } \\
\text { meander } \\
\text { dan garis } \\
\text { horisontal } \\
\text { dan vertikal } \\
\text { (silang) }\end{array}$ & $\begin{array}{l}\text { Qing, abad } \\
\text { ke-18-20 M }\end{array}$ & \\
\hline & & Porselen/sendok & Tepian/2 & $\begin{array}{l}\text { Underglazed biru } \\
\text { putih }\end{array}$ & Flora & $\begin{array}{l}\text { Qing, abad } \\
\text { ke-18-20 M }\end{array}$ & \\
\hline & & Porselen/sendok & Tepian/1 & Glasir hijau terang & $\begin{array}{l}\text { Polos, ada } \\
\text { cap di } \\
\text { bawah } \\
\text { sendok }\end{array}$ & ? & \\
\hline & & Porselen/piring & $\begin{array}{l}\text { Badan/5; } \\
\text { tepian/4; } \\
\text { dasar/1 }\end{array}$ & $\begin{array}{l}\text { Underglazed biru } \\
\text { putih }\end{array}$ & $\begin{array}{l}\text { Geometris } \\
\text { dan flora }\end{array}$ & $\begin{array}{l}\text { Eropa, abad } \\
\text { ke-20 M }\end{array}$ & \\
\hline & & Porselen/piring & Tepian/1 & $\begin{array}{l}\text { Uderglazed biru } \\
\text { putih }\end{array}$ & $\begin{array}{l}\text { Garis warna } \\
\text { biru tebal }\end{array}$ & $\begin{array}{l}\text { Eropa, abad } \\
\text { ke-20 M }\end{array}$ & \\
\hline & & Porselen/piring & Tepian/1 & Glasir hijau putih & & $\begin{array}{l}\text { Eropa, abad } \\
\text { ke-20 M }\end{array}$ & \\
\hline & & Porselen/piring & Tepian/2 & Polikrom & & $\begin{array}{l}\text { Eropa, abad } \\
\text { ke- } 20 \mathrm{M}\end{array}$ & \\
\hline & & Porselen/piring & $\begin{array}{l}\text { Tepian } / 1 ; \\
\text { badan/4 }\end{array}$ & Glasir putih & Polos & $\begin{array}{l}\text { Modern, } \\
\text { abad ke-21 } \\
\text { M }\end{array}$ & \\
\hline & & Porselen/cangkir & Tepian/1 & Glasir putih & Polos & $\begin{array}{l}\text { Modern, } \\
\text { abad ke-21 } \\
\text { M }\end{array}$ & \\
\hline & & Porselen/teko & Karinasi/1 & Glasir putih & Polos & $\begin{array}{l}\text { Modern, } \\
\text { abad ke-21 } \\
\text { M }\end{array}$ & \\
\hline & 1 & Porselen/mangkuk & $\begin{array}{l}\text { Dasar/2; } \\
\text { tepian/1 }\end{array}$ & Glasir putih & Polos & $\begin{array}{l}\text { Modern, } \\
\text { abad ke-21 } \\
\text { M }\end{array}$ & \\
\hline & & Porselen/piring & $\begin{array}{l}\text { Tepian/3; } \\
\text { dasar/1 }\end{array}$ & Glasir putih & Polos & $\begin{array}{l}\text { Modern, } \\
\text { abad ke-21 } \\
\text { M }\end{array}$ & $\begin{array}{l}\text { Dasar } \\
\text { bentuk } \\
\text { cincin }\end{array}$ \\
\hline & & Porselen/piring & $\begin{array}{l}\text { Tepian/13; } \\
\text { dasar/3; } \\
\text { badan/17 }\end{array}$ & $\begin{array}{l}\text { Glasir putih, } \\
\text { pecah seribu }\end{array}$ & Polos & $\begin{array}{l}\text { Eropa, abad } \\
\text { ke-20 M }\end{array}$ & $\begin{array}{l}\text { Dasar } \\
\text { bentuk } \\
\text { cincin } \\
\text { rendah }\end{array}$ \\
\hline & & Porselen/dish & $\begin{array}{l}\text { Dasar/1; } \\
\text { tepian/1; } \\
\text { badan/1 }\end{array}$ & $\begin{array}{l}\text { Glasir dasar putih, } \\
\text { polikrom }\end{array}$ & Flora & $\begin{array}{l}\text { Eropa, abad } \\
\text { ke-20 M }\end{array}$ & \\
\hline & & $\begin{array}{l}\text { Porselen/piring besar } \\
\text { (dish) }\end{array}$ & $\begin{array}{l}\text { Tepian/1; } \\
\text { dasar/2 }\end{array}$ & Glasir biru putih & Geometris & $\begin{array}{l}\text { Qing, abad } \\
\text { ke-18-20 M }\end{array}$ & \\
\hline & & Porselen/mangkuk & Tepian/1; & Glasir biru putih & Geometris & Qing, abad & \\
\hline
\end{tabular}




\begin{tabular}{|c|c|c|c|c|c|c|c|}
\hline No. & Kotak/spit & Bahan/bentuk & Jenis/jumlah & Glasir & Motif hias & periodisasi & Ket \\
\hline & & & badan $/ 6$ & & & ke-18-20 M & \\
\hline & & Porselen/dish & $\begin{array}{l}\text { Dasar/1; } \\
\text { tepian/1 }\end{array}$ & Glasir biru putih & Flora & $\begin{array}{l}\text { Qing, abad } \\
\text { ke-18-20 M }\end{array}$ & \\
\hline & & Porselen/piring & Tepian/1 & Glasir biru putih & $\begin{array}{l}\text { Geometris, } \\
\text { flora }\end{array}$ & $\begin{array}{l}\text { Eropa, abad } \\
\text { ke-20 M }\end{array}$ & \\
\hline & 2 & Porselen/piring & $\begin{array}{l}\text { Tepian/3; } \\
\text { badan/5 }\end{array}$ & Glasir putih & Polos & $\begin{array}{l}\text { Eropa, abad } \\
\text { ke-20 M }\end{array}$ & \\
\hline & & Porselen/piring & Badan/1 & Glasir biru putih & Flora & $\begin{array}{l}\text { Eropa, abad } \\
\text { ke-20 M }\end{array}$ & \\
\hline & & Porselen/wadah & Badan/1 & Glasir biru hijau & & $\begin{array}{l}\text { Eropa, abad } \\
\text { ke-20 M }\end{array}$ & \\
\hline & & Porselen/piring & Tepian/1 & $\begin{array}{l}\text { Glasir putih, } \\
\text { polikrom (biru, } \\
\text { merah) }\end{array}$ & Flora & $\begin{array}{l}\text { Eropa, abad } \\
\text { ke-20 M }\end{array}$ & \\
\hline & & Porselen/mangkuk & Tepian/1 & $\begin{array}{l}\text { Glasir hijau, } \\
\text { seladon }\end{array}$ & Polos & $\begin{array}{l}\text { Yuan (?), } \\
\text { glasir tipis }\end{array}$ & \\
\hline & & Porselen/piring & $\begin{array}{l}\text { Tepian/2; } \\
\text { badan/2 }\end{array}$ & $\begin{array}{l}\text { Underglazed biru } \\
\text { putih }\end{array}$ & Geometris & $\begin{array}{l}\text { Qing, abad } \\
\text { ke-18-20 M }\end{array}$ & \\
\hline & & Stoneware/tempayan & Badan/7 & Glasir cokelat tua & Polos & Qing (?) & \\
\hline & & Porselen/piring & Dasar/1 & $\begin{array}{l}\text { Underglazed biru } \\
\text { putih }\end{array}$ & Flora & $\begin{array}{l}\text { Qing, abad } \\
\text { ke-18-20 M }\end{array}$ & \\
\hline & 3 & Porselen/piring & $\begin{array}{l}\text { Tepian/1; } \\
\text { badan/1 }\end{array}$ & $\begin{array}{l}\text { Underglazed biru } \\
\text { putih }\end{array}$ & Geometris & $\begin{array}{l}\text { Qing, abad } \\
\text { ke-18-20 M }\end{array}$ & \\
\hline & & Porselen/piring & $\begin{array}{l}\text { Tepian/1; } \\
\text { badan/1 }\end{array}$ & $\begin{array}{l}\text { Underglazed biru } \\
\text { putih }\end{array}$ & $\begin{array}{l}\text { Flora dan } \\
\text { geometris }\end{array}$ & $\begin{array}{l}\text { Eropa, abad } \\
\text { ke-20 M }\end{array}$ & \\
\hline & & Stoneware/tempayan & Badan/4 & Tanpa glasir & Polos & Lokal? & \\
\hline & & Stoneware/tempayan & Badan/1 & Glasir cokelat & Polos & $\begin{array}{l}\text { Qing, abad } \\
\text { ke-18-20 M }\end{array}$ & \\
\hline \multirow[t]{4}{*}{4} & TP 4/1 & Porselen/wadah & Badan/4 & $\begin{array}{l}\text { Underglazed biru } \\
\text { putih }\end{array}$ & Geometris & $\begin{array}{l}\text { Qing, 18-20 } \\
M\end{array}$ & \\
\hline & & Stoneware/pasu & Tepian/1 & Glasir hijau & Polos & $\begin{array}{l}\text { Qing, abad } \\
\text { ke-18-20 M }\end{array}$ & \\
\hline & & Porselen/wadah & Dasar/2 & $\begin{array}{l}\text { Gasir putih pecah } \\
\text { seribu }\end{array}$ & Polos & Eropa, $20 \mathrm{M}$ & $\begin{array}{l}\text { Dasar betuk } \\
\text { cincin tinggi }\end{array}$ \\
\hline & & Porselen/wadah & Badan/1 & Glasir putih & Polos & $\begin{array}{l}\text { Modern, } \\
\text { abad ke-21 } \\
\text { M }\end{array}$ & \\
\hline \multirow[t]{7}{*}{5} & TP 5/1 & Porselen/sendok & Tepian/1 & $\begin{array}{l}\text { Underglazed biru } \\
\text { putih }\end{array}$ & Geometris & $\begin{array}{l}\text { Qing, abad } \\
\text { ke-18-20 M }\end{array}$ & \\
\hline & & Porselen/mangkuk & Tepian/1 & Glasir putih & Polos & $\begin{array}{l}\text { Qing, abad } \\
\text { ke-18-20 M }\end{array}$ & \\
\hline & & Porselen/mangkuk & Tepian/1 & $\begin{array}{l}\text { Underglazed biru } \\
\text { putih }\end{array}$ & Geometris & $\begin{array}{l}\text { Qing, abad } \\
\text { ke-18-20 M }\end{array}$ & \\
\hline & & Porselen/mangkuk & Tepian/1 & $\begin{array}{l}\text { Underglazed biru } \\
\text { putih }\end{array}$ & Flora & $\begin{array}{l}\text { Qing, abad } \\
\text { ke-18-20 M }\end{array}$ & \\
\hline & & Porselen/piring & Tepain/1 & $\begin{array}{l}\text { Underglazed biru } \\
\text { putih }\end{array}$ & Flora & $\begin{array}{l}\text { Qing, 18-20 } \\
M\end{array}$ & \\
\hline & & Porselen/wadah & Badan/1 & $\begin{array}{l}\text { Underglazed biru } \\
\text { putih }\end{array}$ & & $\begin{array}{l}\text { Qing, abad } \\
\text { ke-18-20 M }\end{array}$ & \\
\hline & 2 & Porselen/wadah & Badan/1 & $\begin{array}{l}\text { Underglazed biru } \\
\text { putih }\end{array}$ & & $\begin{array}{l}\text { Qing, abad } \\
\text { ke-18-20 M }\end{array}$ & \\
\hline
\end{tabular}

Sumber : hasil penelitian 2014 
Pusat Kerajaan Tayan di Bukit Rayang, Sanggau, Kalimantan Barat-Sunarningsih dan Yuka Nurtanti Cahyaningtyas (73-90) Doi: $10.24832 /$ ke.v7i2.102

Tabel 9 Hasil Analisis Temuan Fragmen Gerabah Ekskavasi

\begin{tabular}{|c|c|c|c|c|c|}
\hline No. & Kotak/Spit & Bahan/bentuk & Jenis/jumlah & Motif hias & Keterangan \\
\hline \multirow[t]{7}{*}{1.} & TP 1/P & Earthenware/wadah & Badan/1 & Polos & $\begin{array}{l}\text { Penampang lintang hitam dengan sisi luar } \\
\text { diupam dan sisi dalam tidak rata. Di buat dengan } \\
\text { sistem tatap pelandas }\end{array}$ \\
\hline & TP 1/1 & Earthenware/tempayan & Tepian/3 & Polos & $\begin{array}{l}\text { Bentuk tepian berbeda, tipis keluar dan tebal } \\
\text { keluar }\end{array}$ \\
\hline & & Earthenware/mangkuk & Tepian/1 & Polos & Tepian melengkung keluar \\
\hline & & Earthenware/wadah & $\begin{array}{l}\text { Badan } \\
\text { tebal/18; } \\
\text { badan tipi/2 }\end{array}$ & Polos & \\
\hline & & Earthenware/tempayan & Karinasi/1 & Polos & \\
\hline & & Earthenware/wadah & Badan/1 & $\begin{array}{l}\text { Hias gores } \\
\text { garis lurus }\end{array}$ & \\
\hline & & Earthenware/wadah & Badan/1 & $\begin{array}{l}\text { Warna merah, } \\
\text { polos }\end{array}$ & \\
\hline \multirow[t]{4}{*}{2} & TP $5 / p$ & Earthenware/wadah & Badan/1 & Polos & $\begin{array}{l}\text { Bekas roda putar jelas terlihat di bagian luar dan } \\
\text { dalam wadah }\end{array}$ \\
\hline & & Earthenware/wadah & Badan/1 & Polos & $\begin{array}{l}\text { Bekas roda putar jelas terlihat di bagian dalam } \\
\text { wadah }\end{array}$ \\
\hline & & Earthenware/wadah & Badan/1 & $\begin{array}{l}\text { Warna putih } \\
\text { keabuan }\end{array}$ & \\
\hline & & Earthenware /wadah & Badan/1 & $\begin{array}{l}\text { Tebal, warna } \\
\text { cokelat } \\
\text { kehitaman }\end{array}$ & \\
\hline
\end{tabular}

Sumber : hasil penelitian 2014

Tabel 10 Hasil AnalisisTemuan Fragmen Kaca Ekskavasi

\begin{tabular}{|c|c|c|c|c|c|}
\hline No. & Kotak/Spit & Bahan/bentuk & jumlah & warna & Keterangan \\
\hline \multirow[t]{2}{*}{1} & TP $1 / p$ & Kaca bening/botol & 1 & putih & \\
\hline & & Kaca bening/tutup & 1 & putih & berornamen \\
\hline \multirow[t]{6}{*}{2} & TP 1/1 & Kaca bening/botol bulat & 5 & Hijau & \\
\hline & & Kaca bening/botol kotak & 5 & Hijau & \\
\hline & & Kaca bening/botol & 1 & biru & \\
\hline & & Kaca bening/botol? & 3 & putih & \\
\hline & & Kaca bening/tutup botol & $\begin{array}{l}\text { 1/bentuk bulat; } 1 \\
\text { bentuk kotak }\end{array}$ & Putih & \\
\hline & & Kaca bening/botol & 2 & putih & Badan bergalur, tidak rata \\
\hline \multirow[t]{6}{*}{3} & $\mathrm{TP} 2 / \mathrm{p}$ & Kaca bening/botol & 9 & Hijau & \\
\hline & & Kaca bening/botol & 9 & putih & \\
\hline & 1 & Kaca bening/semprong & 2/tipis & Putih & \\
\hline & & Kaca bening/wadah & 1 & Hijau & \\
\hline & & Kaca/wadah & 1 & $\begin{array}{l}\text { Putih } \\
\text { susu }\end{array}$ & Bergalur, bagian badan \\
\hline & 2 & Kaca bening/bukan wadah & 1/tipis & putih & \\
\hline
\end{tabular}

Sumber : hasil penelitian 2014 